However catastrophic in its occurrence the distribution of the Drift may have been, it is obvious that the progress made by man in his passage from the Palæothic to the Neolithic stage was not characterized by that suddenness which is ordinarily associated with the term. Of the history of that progress, of the place of man's abode during it, we know nothing. There is a true 'gap' or 'break.'

In geology and archæology these two words simply imply that our knowledge as to the periods of time concerned is imperfect, and we always expect to find certain of the missing links of the chain of evidence come to light, which they sometimes do in unexpected places.

Is there any link to be found, however remote, to help to bridge over that extraordinary gap between Palæolithic man and his Neolithic successors? I believe there is one, and that it is to be found in the almost universal tradition of a 'deluge'-a tradition which appears to me to have been handed down from our Palæolithic ancestors through the Neolithic, Bronze, and Iron ages of their successors, and to have reached us as a dim and misty conception of their ideas of the-let us call it very bad weather-of the Pleistocene Period. That the story as conveyed to us from Asiatic sources is very different from that written on the page of the rocks in Northern Europe, is not surprising. All tradition undergoes a process of corruption as it is handed down from age to age, and the particular form in which the deluge tradition has reached us is obviously no exception to the rule. Unfortunately, when such a theory is advanced, it is usually seized upon as a confirmation of the miraculous inspiration of Scripture. It is no such thing.

I cannot claim originality for the theory, because I find in Mr. Tiddeman's "Work and Problems of the Victoria Cave Exploration," 1875, the following passage:- "As similar evidences of a submergence late in the glacial period have been observed over large areas in the Old and the Now World, and in both hemispheres, in mean latitudes, it may be that the traditions so common to many races and religions of a great deluge are but lingering memories of this great event. It matters not that these myths all differ in their surroundings. The central core still has the solid ring of truth, albeit masked and disfigured by the rust of time."

I venture to suggest that the theory that the deluge tradition is the one and only link which bridges over the gap between Palæolithic man and ourselves, his descendants, is one which is worthy of more attention than it has hitherto received.

“ Hay Tor," Dennnington Park Road, Hampstead.

J. Adam Watson. August 18, 1901.

\title{
EOLITHIC MAN.
}

Sre,-It is remarkable that in a quasi-geological paper by a wellknown writer should bave been allowed to pass current such a statement as that at p. 340 (GEoc. MAG., August issue), to the effect that "Huxley caused McEnery's now famous memoir to be 
locked up at the Royal Society for years after his death." The Rev. McEnery's reports on Kents Cavern were finished about 1826, and Professor Huxley having been born in 1825 must have been always under age and without influence in the Royal Society whilst McEnery's paper was supposed to be "lost," but really kept in the background by influence of the Rev. Dean Buckland, who ascribed the occurrence of anything like human implements to burials of late date, as I myself have heard him affirm at a meeting of the Geological Society.

The reference to Professor Huxley in the paper alluded to above is probably only one of the evidences of the hasty character of the paper; but at first sight it appears, not only uncalled for, but unkind.

Some of his friends, like the writer of this critique, will regret Sir H. Howorth's inability to recognize the actual classification of eoliths as practically established by Prestwich, and illustrated in his own and B. Harrison's collections, as well as in the Museum of the Geological Survey, Royal College of Science, the British Museum (Natural History Branch), and elsewhere. Also, it is lamentable that he cannot appreciate Prestwich's lucid explanation of the geological history and settlement of the eolithic gravel of the Chalk Downs, as reproduced in Mr. Bullen's pamphlet, to which he alludes es having read.

To other shortcomings we need not refer; it is a pity that there should be any, for the author is doubtless an industrious gatherer of facts and notions, evidently so when he seems to have searched one set of about twenty volumes, "1829-50" (!), for the history of Ami Boués discovery of bones near the Lahr (p. 339).

\section{T. RUPERT JoNes.}

\section{EOLITHIC IMPLEMENTS.}

Sir,-Sir H. H. Howorth, F.R.S., has done me the honour of mentioning in the Geological Magazine for August my little paper on the above subject.

Like Balaam, having set himself to curse Israel, he has instead blessed them altogether. On p. 342 he says (assuming their identity with palæoliths), "Such remains are claimed to have been found at that horizon [the Forest Bed] in Norfolk by Mr. Abbott and Mr. Savin, in Dorsetshire by Dr. Blackmore, and they have been also reported from the same horizon at St. Prest in France and in the Val d'Arno, north of Italy, in each case the remains of human workmanship being accompanied by those of $E$. meridionalis. I believe these finds are quite genuine." (Italics mine.) The implements referred to as Dr. Blackmore's, pl. iii in my paper, have, as a matter of fact, an eolithic facies, and Sir H. H. Howorth's admission concedes all that for which Sir Joseph Prestwich's followers contend. "I thank thee, Roderick, for that word!"

Sir Henry mentions five men as upholding eoliths, including their original discoverer, Mr. Benjamin Harrison, and that paladin of 